\title{
Taze ve Örgü Peynirlerinde Doğal Yolla Meydana Gelen Benzoik Asit Miktarının Belirlenmesi
}

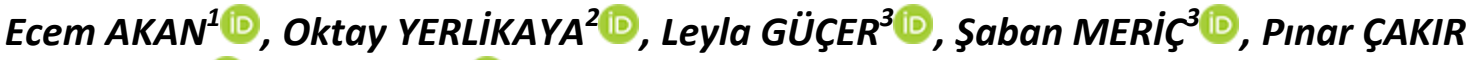 TOPDEMIR $^{3}$ (D) ÖZer KINIK ${ }^{2}$}

\author{
${ }^{1}$ Aydın Adnan Menderes Üniversitesi, Ziraat Fakültesi, Süt Teknolojisi Bölümü, 09970, Koçarlı, Aydın, Türkiye \\ ${ }^{2}$ Ege Üniversitesi, Ziraat Fakültesi, Süt Teknolojisi Bölümü, 35100, Bornova, İzmir, Türkiye \\ ${ }^{3}$ T.C. Tarım ve Orman Bakanlığı, Izmir il Gıda Kontrol Laboratuvar Müdürlüğü, 35100, Bornova, İmir, Türkiye
}

Öz: Aromatik karboksilik asit ailesinin en basit üyesi olan benzoik asit, birçok önemli organik bileşiğin sentezinde öncü maddedir. Her ne kadar gıdalarda mikroorganizma kaynaklı bozulmaları önlemek amacıyla kullanıldığı düşünülse de yapılan araştırmalar benzoik asidin çeşitli peynir tiplerinde farklı konsantrasyonlarda bulunabildiğini göstermektedir. Bu çalışmada yöresel peynir çeşitlerimizden taze ve örgü peynirlerinin depolama süresince hippurik ve benzoik asit miktarları tespit edilerek tespit edilen miktarların peynirin bazı fizikokimyasal ve mikrobiyolojik özellikleri ile ilişkilendirilmesine çalışılmıştır. Peynirlerin üretiminde kullanılan çiğ sütlerde hippurik asit ve benzoik asit tespit edilmiştir. Depolama süresince peynirlerin benzoik asit miktarları 4,73-11,42 mg/kg aralığında değişiklik göstermiştir. Depolama süresi sonunda depolamanın başlangıcına göre örgü peynirde benzoik asit miktarı önemli düzeyde azalırken, Taze peynirde artmıştır $(p<0,05)$. Benzoik asit miktarı yüksek olan taze peynirlerde Lactococcus spp. ve Enterococcus spp. sayılarının daha yüksek, Lactobacillus spp. ve maya-küf sayılarının daha düşük olduğu görülmüştür. Sonuç olarak çiğ sütte, taze ve örgü peynirlerinde doğal yolla benzoik asitin oluştuğu ve düzeylerinin yaklaşı $12 \mathrm{mg} / \mathrm{kg}^{\prime}$ a ulaştığı belirlenmiştir.

Anahtar kelimeler: Benzoik asit, hippurik asit, taze peynir, örgü peyniri, yöresel peynirler

Determination of Naturally Occuring Benzoic Acid in Fresh and Braided (Orgu) Cheese

Abstract: Benzoic acid, the simplest member of the aromatic carboxylic acid family, is a precursor in the synthesis of many important organic compounds. Although it is thought to be used to prevent microorganism-induced spoilage in foods, researches have shown that benzoic acid can be found in different concentrations in various cheese types. In this study, hippuric and benzoic acid amounts of fresh and braided cheeses of our local cheese varieties were determined during storage. In addition, it was tried to associate the hippuric and benzoic acid amounts with some physicochemical and microbiological properties of cheeses. Hippuric acid and benzoic acid were detected in the raw milk used in the production of cheeses. During the storage period, the amount of benzoic acid in the cheeses varied in the range of $4.73-$ $11.42 \mathrm{mg} / \mathrm{kg}$. At the end of the storage period compared to the beginning of storage, the amount of benzoic acid decreased significantly in braided cheese, while it increased in fresh cheese $(p<0.05)$. In fresh cheeses with high benzoic acid content, Lactococcus spp. and Enterococcus spp. higher numbers of Lactobacillus spp. and yeast-mold counts were lower. As a result, it was determined that benzoic acid was formed naturally in raw milk, fresh and braided cheeses and its levels reached approximately $12 \mathrm{mg} / \mathrm{kg}$.

Keywords: Benzoic Acid, hippuric acid, fresh cheese, Braided cheese, local cheeses

\section{GiRiş}

Benzoik, sorbik, propiyonik asit gibi antimikrobiyallerin bir kısmı gıdalarda doğal olarak bulunabildiği gibi bir kısmı da fermantasyon sırasında meydana gelebilmektedir (Yun ve ark., 2019; Garmiene ve ark., 2011; Horníčková, 2014; Urbiene ve Leskausklite, 2006). Benzoik, sorbik ve propiyonik asit, süt ve süt ürünlerinde düşük miktarlarda bulunmakta ve bu maddeler antibakteriyel özellikleri nedeniyle de büyük önem arz etmektedir. Bu antimikrobiyal özellikteki maddeler maya, küf ve bakterilere karşı inhibe edici etki göstermektedir (Park ve ark, 2016). Benzoik asit antimikrobiyal olarak ABD Gıda ve İlaç İdaresi'ne göre güvenli olarak sınıflandırılmaktadır. Buna karşın benzoik asitin astım, ürtiker, metabolik asidosis ve istemsiz kasılma gibi olumsuz etkileri bulunduğu bildirilmekte ve özellikle de anılan belirtiler duyarlı bireylerde çok düşük konsantrasyonlarda bile ortaya çıkabilmektedir (Park ve ark., 2016; Qi ve ark., 2009; Shahmohammadi ve ark., 2016).

Benzoik asit, sütün doğal bir bileşeni olan hippurik asitten fermantasyon sonucunda meydana gelmektedir. Oluşan benzoik asit düzeyinin çiğ sütün mikrobiyal kalitesi ile de ilişkisi bulunmaktadır. Özellikle laktik asit bakterileri sütte doğal olarak bulunan hippurik asidi benzoik aside dönüştürmekte ve böylece benzoik asit süt ve süt

*Sorumlu Yazar: oktay.yerlikaya@ege.edu.tr Bu çalışma T.C. Tarım ve Orman Bakanlığı Tarımsal Araştırmalar ve Politikalar Genel Müdürlüğü ve Ege Üniversitesi Süt Teknolojisi Bölümü ile ortaklaşa yürütülmüştür.

(Proje numarası: TAGEM/HSGYAD/14/A05/P01/57)

Geliş Tarihi: 27 Eylül 2021

Kabul Tarihi: 28 Aralık 2021 
ürünlerinin doğal bir bileşeni olarak meydana gelebilmektedir. Fermente ürünlerde benzoik asit oluşumunda öngörülen ikinci bir metabolik yol ise olgunlaşma ya da depolama sırasında $\beta$-fenil-propiyonik (hidrosinamik) asit ve sinnamik asit ara ürünlerinin oluşturduğu fenilalaninin bozunma reaksiyonudur (Leuthardt, 1977). Muhtemel üçüncü bir yol da laktik asit bakterilerinin belirli suşları tarafından üretilen benzaldehidin oto-oksidasyonu şeklinde gerçekleşebilmektedir. Kısaca hippurik asidin dönüşümüne ek olarak bahsedilen bu iki yol (fenilalalinin degradasyonu ve benzaldehidin oto-oksidasyonu) fermente süt ürünleri ve peynirlerde benzoik asidin oluşumuna neden olabilmektedir. Peynirde benzoik asit oluşumu ile ilgili diğer muhtemel bir mekanizma ise başta Gruyére peyniri olmak üzere diğer peynir çeşitlerinde de bulunabilen fenollü aminoasitlerin anaerobik metabolizması şeklinde açıklanmaktadır (Londry ve Fedorak, 1992). Peynirlerdeki benzoik asit düzeylerinde pıhtı oluşumu ve peynir çeşidinin etkili olduğu belirtilen bir çalışmada ticari doğal peynirlerde benzoik asit miktarı 0-4,2 mg/kg, proses peynirlerinde ise 020,8 mg/kg aralığında olduğu saptanmıştır (Lim ve ark., 2013).

Sütün doğal yapısında iz miktarda benzoik asit bulunmakla birlikte yoğurt, meyveli yoğurt, bifidobakteri ve laktobasil türleri ile fermente edilmiş süt ürünleri, kefir, kımız gibi fermente ürünler ortalama $20 \mathrm{mg} / \mathrm{kg}$ civarı benzoik asit içerebilmektedir (Sieber ve ark., 1995). Lactococcus lactis, Escherichia coli, Pseudomonas fluorescens gibi bakteri türleri de benzoik asit üretme yeteneğindedir (Sieber ve ark., 1995; Yun ve ark., 2017). Benzoik asit, Quark, Cottage, bazı taze sert ve yarı sert peynirlerde de doğal yol ile meydana gelebilmektedir. Yüzey olgunlaşması yoluyla üretilen peynirlerde fermente süt ürünlerine göre önemli düzeylerde düşük benzoik asit oluşmasına karşın uzun süreli olgunlaştırılan veya starter kültür kullanılan peynir çeşitlerinde daha yüksek oranlarda benzoik asit oluşabilmektedir (Sieber ve ark., 1995, Gücer ve ark., 2016; Chandan ve ark., 1977; Overstrom ve ark., 1972).

Avrupa Birliği yönetmeliklerine göre benzoik asidin günlük alınmasına izin verilen miktarı (ADI değeri) $5 \mathrm{mg} / \mathrm{kg}$ ya da $350 \mathrm{mg} / 70 \mathrm{~kg}$ vücut ağırlığı olarak belirlenmiştir (Shahmohammadi ve ark., 2016, Olmo ve ark., 2017). Nitekim bu amaç doğrultusunda gıda katkı maddelerinin güvenle kullanımı farklı ülkelerde özel yönetmeliklerle güvence altına alınmıştır. Birçok ülkede olduğu gibi Türkiye'de de benzoik asit ve tuzlarının yoğurt, peynir, domates salçası ve sosları, meyve suları, çikolatalar, dehidre çorbalar ve cipslerde kullanımı yasaklanmıştır. Bu nedenle yapılan bu çalışmada ülkemizde en çok bilinen ve piyasada değişik adlar ile pazarlanan taze ve örgü peynirlerinin 294 üretim ve depolanmaları sırasında doğal yolla meydana gelen benzoik asit miktarının tespiti ve benzoik asit oluşumu üzerine etki eden bazı faktörlerin araştırılması amaçlanmıştır.

\section{MATERYAL VE YÖNTEM}

\section{Materyal}

Çalışmamızda İzmir ve çevresinde faaliyet gösteren üç farklı işletmeden (Gürsüt Mam. San. ve Tic. Ltd. Şti., Balkan Süt. Ür. San. Tic. Ltd. Şti., Yallıoğlu Tar. Ür. San. Tic. Ltd.Şti.) tedarik edilen taze peynir ve örgü peynirleri kullanılmıştır. Her peynir çeşidi 2 farklı işletmeden olacak şekilde üretilmiştir.

\section{Metot}

\section{Taze peynir üretimi}

İşletmeye gelen çiğ süt $55-60{ }^{\circ} \mathrm{C}$ 'ye kadar ısıtılmış ve krema seperatöründen geçirilerek yağın bir bölümü ayrılmıştır. Daha sonra $87-90^{\circ} \mathrm{C}^{\prime}$ de $15-20$ dakika pastörize edilen süt mayalama sıcaklığına $\left(47-50{ }^{\circ} \mathrm{C}\right)$ kadar soğutulmuş ve mayalama işlemi için Bulgar usulü peynir teknelerine alınmıştır. Peynir teknelerine alınan süte kalsiyum klorür ilavesi yapılarak peynir mayası ilave edilmiştir. Mayalanan sütler pıhtı oluşumu için 45 dakika kadar bekletilerek pıhtı kırma işlemi gerçekleşmiş ve pıhtı cendere bezi içinde 10-15 dk olgunlaşmaya bırakılmıştır. Daha sonra peynir altı suyu ortamdan uzaklaştırılarak oluşan telemeler bezler içine alınarak şekil verilmiş ve 15-20 dk süre ile baskıya alınmıştır. Baskılama işleminden sonra oluşan peynirler bezleri ile birlikte 15 bome derecelik salamurada 12-15 saat süre ile soğuk hava depolarında bekletilmiştir. Bekleme süresinden sonra peynirler plastik kovalar içerisinde soğuk hava deposunda $+4{ }^{\circ} \mathrm{C}^{\prime}$ de depolanmıştır.

\section{Örgü Peyniri Üretimi}

Örgü Peyniri üretiminde kullanılan sütler ölçüm tankına alınıp ön süzülme işlemi için boru filtreden sonra klarifikatörden geçirilerek temizlenmiş ve soğutma tankına alınmıştır. Sonraki aşamada süt $65^{\circ} \mathrm{C}^{\prime} \mathrm{de} 10 \mathrm{dk}$ pastörize edilmiş ve mayalama sıcaklığına $\left(36{ }^{\circ} \mathrm{C}\right)$ kadar soğutulmuştur. Süt kapalı boru sistemiyle proses tankına alınarak süte starter kültür ilavesi (Lactococcus lactis subsp. lactis / Streptococcus thermophilus) yapılmış ve sütte bir ön aktivasyon ortamı yaratılmıştır. İnoküle süt $36^{\circ} \mathrm{C}^{\prime}$ de 30 dakika süreyle inkübasyona bırakılmıştır. Bunu izleyen aşamada proses tankına alınan sütlere \%0,02 oranında kalsiyum klorür ilavesi yapılmıştır. Proses tankına alınan süt iyice karıştırıldıktan sonra 45-60 dakikada pıhtı kırıma gelecek şekilde \%0,01-0,015 oranında peynir mayası ilave edilmiştir. Pıhtı kırıldıktan sonra teleme ve peynir altı suyuna $35-40{ }^{\circ} \mathrm{C}$ arasında Isı verilerek peynir altı suyu ile teleme birbirinden ayrılmıştır. Peynir altı suyundan ayrılan teleme, 1- 2 saat teknede bekletilmiş ve telemenin içindeki peynir altı suyu tamamen ayrılmıştır. Teleme istenen $\mathrm{pH}$ 
(5.40-5.50) seviyesine geldiğinde peynir kıyma makinesinden geçirilen teleme $\% 5$ tuz konsantrasyonuna göre hazırlanmış ve pastörize edilip $75^{\circ} \mathrm{C}$ ye soğutulmuş haşlama suyu kullanılarak sulu haşlama makinesinde haşlama işlemi yapılmıştır. Bu aşamada çekilerek örgü şekli verilen örgü peyniri \%10'luk pastörize edilmiş salamuralar içinde, 12 saat bekletilmiştir. Kurutma işlemi tamamlanan şeklini almış peynirler gramajlarına uygun olarak polipropilen ambalajlarda paketlenmiştir. Ambalajlanan peynirler $+4 \mathrm{C}^{\circ}$ de soğuk hava koşullarında depolanmıştır.

\section{Peynirlerde Yapılan Analizler}

\section{Fizikokimyasal Analizler}

Kuru madde: Peynir örneklerinde kuru madde oranları, 3-5 g örneğin $105 \pm 2{ }^{\circ} C^{\prime}$ de sabit tartıma gelinceye kadar kurutulması ile gravimetrik olarak belirlenmiştir (AOAC, 1997).

Yağ: Peynirlerin yağ oranları, 0-40 taksimatlı özel peynir bütirometreleri ile Gerber yöntemine göre belirlenmiştir (AOAC, 1997).

Tuz : Tuz oranları Mohr titrasyon yöntemine göre, hazırlanan örneğin ayarlı 0,1 $\mathrm{N} \mathrm{AgNO}_{3}$ ile titrasyonu sonucu belirlenmiştir (AOAC, 1997). Sonuçlar \% olarak ifade edilmiştir.

Toplam azot ve protein: Peynirlerdeki toplam azot ve protein miktarları İzmir il Kontrol Laboratuvar Müdürlüğü'nde bulunan tam otomatik nitrojen ve protein ölçüm cihazı Leco FP-528 (USA) kullanılarak belirlenmiştir. Analiz edilecek peynir örneği aliminyum içerisine tartılarak cihaz haznesine yerleştirilmiş ve yakma işlemini tamamladıktan saptanan azot miktarları 6,38 katsayısı ile çarpılarak protein oranı belirlenmiştir (Renner, 1993).

Serbest yağ asitleri (SYA) Değeri: Serbest yağ asidi miktarını gösteren asit değeri Renner (1993)'e göre belirlenmiştir. 8$10 \mathrm{~g}$ arasında yağ elde edilecek şekilde tartılan peynir örnekleri bir beher içerisine konmuş, üzerine kselgur eklenmiştir. Havan tokmağı yardımıyla yağ globül membranının parçalanması sağlanarak karışımın yağ oranı artırılmıştır. Daha sonra saf dietil eter yardımıyla üç kez yıkanarak yağ ekstraksiyonu sağlanmış, ekstrat kaba filtre kağıdından süzülerek eter-yağ karışımı elde edilmiş ve rotari evaporatörde $45{ }^{\circ} \mathrm{C}^{\prime}$ de eter uzaklaştırılarak saf yağ alınmıştır. Yağ $45{ }^{\circ} C^{\prime} l i k$ su banyosunda eter kokusu tamamen yok olana kadar bekletilmiştir. Tartılan $4 \mathrm{~g}$ yağ örneği üzerine $40 \mathrm{~mL}$ alkol-eter karışımı (1:1) ilave edilerek, alkolde hazırlanmış $0,1 \mathrm{~N} \mathrm{KOH}$ ile \%1'lik fenolfitalein yardımı ile titre edilmiştir (Renner, 1993). Sonuçlar mg $\mathrm{KOH} / \mathrm{g}$ yağ olarak verilmiştir.

pH ve Titrasyon asitliği:

Peynirlerde $\mathrm{pH}$ ölçümünde rendelenmiş peynir örnekleri iyice sıkıştırılmış, peynir probu kalibre edildikten sonra doğrudan daldırılarak yapılmıştır. pH ölçümünde Hanna 211
AKAN E, YERLIKAYA O, GÜÇER L, MERIÇ Ş, ÇAKIR TOPDEMIR P, KINIK Ö dijital pH-metre kullanılmıştır (Hannon ve ark., 2003). Titrasyon asitliği belirlenirken, peynir örneğinden $10 \mathrm{~g}$ alınıp, havanda ezilip üzerine $10 \mathrm{~mL}$ saf su ilave edilerek homojenize edilmiştir. Elde edilen homojen karışımın asitliği, ayarı $0,1 \mathrm{~N} \mathrm{NaOH}$ ile titre edilerek sonuç \%laktik asit cinsinden ifade edilmiştir (AOAC, 1997).

\section{Benzoik Asit Tayini}

Numuneler tartıldıktan sonra, saf suyla çözülüp 3 paralel olarak analizler gerçekleştirilmiştir. Benzoik asit analizlerinde Prodolliet ve Bruelhart (1993)'ün belirttiği yöntemi kullanılmıştır. Bu yönteme göre örnekten belli bir miktar alınıp, suda çözülmüş, 10 dakika süreyle ultrasonik banyoda tutulup $25^{\circ} \mathrm{C}$ ' de su banyosunda bekletilmiştir. Sonra 5' er mL Carrez I (36 g potasyum hekza siyona ferrat-II trihidrat suda çözülür, saf suyla litreye tamamlanır) ve Carrez II (72 g çinko sülfat heptahidrat saf suyla litreye tamamlanır) eklenip iyice karıştırılmış ve $100 \mathrm{~mL}$ 'ye saf suyla tamamlanmıştır. Karışım 0,45 $\mu \mathrm{m}^{\prime}$ lik fittreden geçirilerek viale alınıp HPLC' ye enjekte edilmiştir.

Standart Stok Çözelti : $1 \mathrm{~g}$ benzoik asit tartılarak ultra saf suyla 1 litreye tamamlanmıştır.

Standart Çalışma Çözeltileri : Stok çözeltiden ultra saf su ile seyreltilerek, uygun konsantrasyonlarda çalışma çözeltileri hazırlanmıştır.

\section{Kromatografik Şartlar:}

Mobil Faz : $1,70 \mathrm{~g} \quad \mathrm{KH}_{2} \mathrm{PO}_{4}$ tartılıp, ultra saf su ile çözülmüştür. $100 \mathrm{~mL}$ asetonitril eklenerek ultra saf su ile litreye tamamlanmıştır. Ultrasonik banyoda degaz edilmiş ve $\% 5^{\prime}$ lik orto-fosforik asit ile $\mathrm{pH}=4,0 \pm 0,3$ 'e ayarlanıp, 0,45 $\mu m^{\prime} l i k$ membran filtreden süzülmüştür.

- $\quad$ Likit Kromatografisi: HPLC

- Dedektör: DAD

- Kolon: $\mu$-Bondapak- C18, $10 \mu \mathrm{m}, 3,9 * 300 \mathrm{~mm}$ RP (Eğer koruyucu ön kolon kullanıldığında GuardPak $\mu$-Bondapak- C18,10 $\mu \mathrm{m}$ precolumn)

- Dalga boyu: SA $262 \mathrm{~nm}$ BA $230 \mathrm{~nm}$

- Akış Hızı: $2 \mathrm{~mL} / \mathrm{dk}$

- Enjeksiyon Hacmi: $20 \mu \mathrm{L}$

- Kolon Sıcaklığı : $40^{\circ} \mathrm{C}$

\section{Geri Kazanım}

Benzoik asit geri alma çalışmasında benzoik asit içermeyen peynir örneği olmadığından öncelikle numunede benzoik asit miktar analizi yapılmış ardından son konsantrasyon 5 $\mathrm{mg} / \mathrm{kg}, 30 \mathrm{mg} / \mathrm{kg}$ ve $45 \mathrm{mg} / \mathrm{kg}$ olacak şekilde standart benzoik asit çözeltisi ilave edilmişve standart analiz metodu rutinde uygulandığı şekilde uygulanmıştır (AOAC, 1993). Elde edilen sonuçlar Çizelge 1 ve Şekil 1'de verilmiştir. Benzoik asit kramotogram görüntüsü ise Şekil 2'de görülmektedir. 
Çizelge 1. Benzoik asit geri kazanım oranları

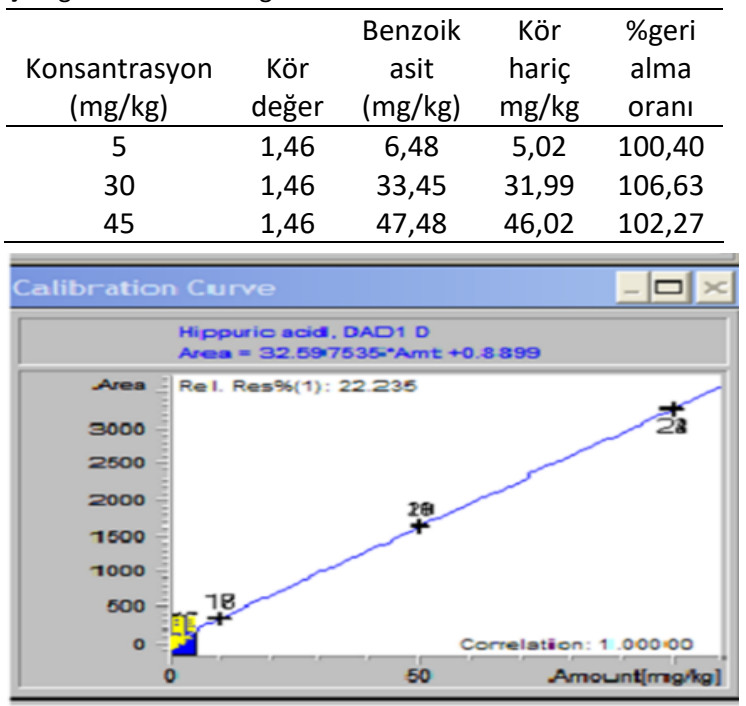

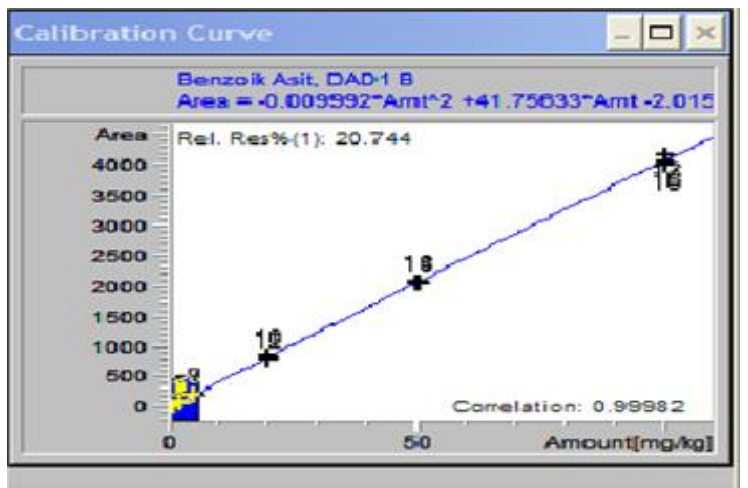

Şekil 1. Hippurik asit ve benzoik asit kalibrasyon eğrileri

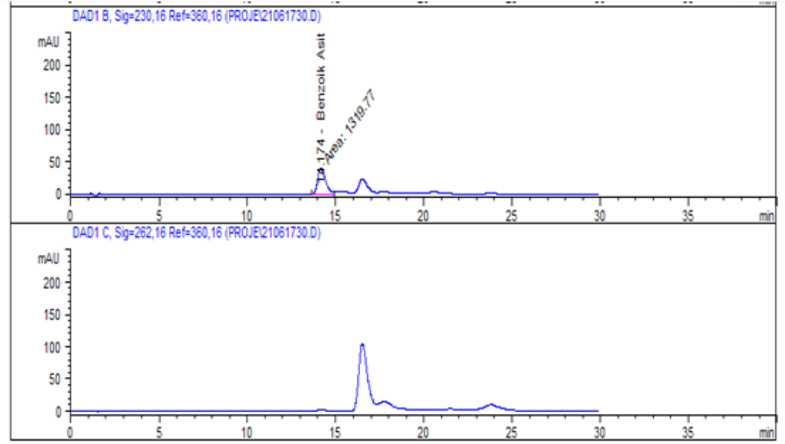

Şekil 2. Benzoik asit kromatogram görüntüsü

\section{Mikrobiyolojik Analizler}

\section{Dilüsyon Sıvılarının ve Besiyerlerinin Hazırlanmas}

Aseptik koşullarda 10 gram peynir örneği, steril stomacker poşetine tartılıp üzerine $90 \mathrm{~mL}$ steril ringer solüsyonu ilave edilmiştir. Karışım iki dakika süreyle homojenize edilmiş ve dilüsyon serileri hazırlanmıştır (Gardiner ve ark., 1999).

\section{Süt Asidi Bakterilerinin Sayımı}

Peynir örneklerindeki laktobasillerin sayımında MRS agar (Merck KGaA Darmstadt, Germany) kullanılmıştır. Uygun dilüsyonlardan paralel inokülasyonu gerçekleştirilen petri kapları $37^{\circ} \mathrm{C}$ 'de 72 saat anaerobik ortamda inkübasyona bırakılmış ve süre sonunda gelişen koloniler sayılmıştır (Bracquart, 1981). Peynir üretiminde kullanılan laktokokların sayımında M17 Agar (Merck KGaA, Darmstadt, Germany) kullanılmış ve $37^{\circ} \mathrm{C}^{\prime}$ de 48 saat inkübasyon sonrasında sayım gerçekleştirilmiştir (Terzaghi ve Sandine, 1975).

\section{Enterococcus spp. Sayımı}

Peynir örneklerindeki Enterococcus ssp. sayımı Kanamycin esculin azide agar besiyeri (Merck KGaA, Darmstadt, Germany) kullanılarak gerçekleştirilmiştir. $37^{\circ} \mathrm{C}^{\prime}$ de 2 günlük inkübasyon sonunda sayım yapılmıştır (Gardiner, 1999).

\section{Maya-Küf Sayımı}

Peynir örneklerinde maya-küf sayımı Yeast Extract Glucose Chloramphenicol Agar (Merck KGaA, Darmstadt, Germany) kullanılarak gerçekleştirilmiştir. Uygun dilisyonlardan ekimi yapılan petri kutuları aerobik olarak $25^{\circ} \mathrm{C}$ 'de 5 gün süreyle inkübasyona bırakılmıştır.

\section{İstatistiksel analiz}

Peynirlerin fizikokimyasal ve mikrobiyal özelliklerinin doğal olarak oluşan benzoik asit oluşumu üzerindeki etkisini belirlemek için One-Way-ANOVA varyans analizi uygulanmıştır. Bu amaçla SPSS versiyon 22.00 (SPSS Inc. Chicago, Illinois) istatistiksel analiz paket programı kullanılmıştır. Varyans analizi sonucunda elde edilen önemli veriler Duncan çoklu karşılaştırma testine göre $p<0,05$ düzeyinde değerlendirilmiştir.

\section{BULGULAR VE TARTIŞMA}

Çalışmamıza konu olan taze peynir ve örgü peynirlerinin genel bazı fizikokimyasal özellikleri Çizelge 2'de verilmiştir. Yukarıda genel özelliklerin verildiği çizelgeden de görülebileceği üzere peynirlerin genel bileşimi Peynir Tebliğine uyum göstermektedir.

Çizelge 2 . Taze ve Örgü peynirlerinin genel fizikokimyasal özellikleri $(n=2)$

\begin{tabular}{cccccc}
$\begin{array}{c}\text { Peynir } \\
\text { çeşidi }\end{array}$ & $\begin{array}{c}\text { Kuru } \\
\text { madde } \\
(\%)\end{array}$ & $\begin{array}{c}\text { Yağ } \\
(\%)\end{array}$ & $\begin{array}{c}\text { Tuz } \\
\mathbf{( \% )}\end{array}$ & $\begin{array}{c}\text { Protein } \\
(\%)\end{array}$ & $\begin{array}{c}\text { SYA değeri } \\
\text { (mg KOH/g } \\
\text { yağ) }\end{array}$ \\
Taze & $45,62 \pm 1$, & $21,25 \pm$ & $3,38 \pm$ & $18,05 \pm$ & $1,64 \pm 0,14$ \\
Peynir & 20 & 1,06 & 0,65 & 1,10 & \\
Örgü & $55,89 \pm 1$, & $24,00 \pm$ & $3,51 \pm$ & $19,08 \pm$ & $1,32 \pm 0,14$ \\
Peyniri & 82 & 1,41 & 0,15 & 1,18 & \\
\hline
\end{tabular}

Piyasada çok farklı tanımlamalarla satılan taze peynirlerde kuru madde \%37,87-42,57; yağ \%16,38-21,25, protein $\% 10,81-15,79$, tuz ise \%5,37-6,54 aralığında değişmektedir. Serbest yağ asitleri değeri ise taze peynirlerde 1,64, örgü peynirlerinde ise $1,32 \mathrm{mg} \mathrm{KOH} / \mathrm{g}$ yağ olarak bulunmuştur. 
Sonuçlara bakıldığında taze peynir örneklerinde kurumadde, yağ, tuz ve protein içeriklerinin daha yüksek, serbest yağ asitleri değerinin ise daha yüksek olduğu belirlenmiştir. Yapılan farklı çalışmalarda örgü peynirlerinde kuru madde \%43,30-63, yağ oranı 13,6- 48,3, tuz oranı $\% 2,45-10,49$, protein oranı ise \%21-\%26,56 aralığında değiştiği belirtilmektedir (Türkoğlu ve ark., 2003; Çelik ve ark., 2007; Karagözlü ve ark., 2016; Kesenkaş ve ark., 2016; Kurt ve ark., 2019). Çalışmamızda elde edilen sonuçlar farklı araştırıcıların saptadıkları değerlere uyum göstermektedir.

$\mathrm{pH}$ ve \%laktik asit cinsinden asitliklere bakıldığında taze peynir örneklerinin $\mathrm{pH}$ değerinin daha düşük, asitliğinin ise daha fazla olduğu görülmektedir (Çizelge 3). Depolama süresince peynirlerin $\mathrm{pH}$ değerlerinde azalma, titrasyon asitliklerinde ise düzenli bir artış belirlenmiştir. Tespit edilen bu değişimler istatistiksel olarak önemli bulunmuştur $(p<0,05)$. Depolama süresi sonunda Taze ve örgü peynirlerin $\mathrm{pH}$ ve asitlik değerleri birbirine yakın seviyelerde seyretmiştir.

Taze peynir ve örgü peynirlerinin üretim aşamaları ve soğukta depolanmaları/olgunlaştırılmaları süresince meydana gelen benzoik asit miktarının değişimi ise Çizelge 4 ve ile Şekil 3' de verilmiştir.

Peynirlerin üretiminde kullanılan çiğ sütlerde benzoik asit miktarları 5,46 $\pm 2,52$ ile 11,91 $\pm 5,22 \mathrm{mg} / \mathrm{L}$ arasında değişmiştir. Yapılan çalışmalarda genelde çiğ sütlerde benzoik asit tespit edilmediği belirtilmektedir (Urbiene ve Leskauskaite. 2006; Heshmati ve ark., 2017). Buna rağmen çalışmamızda çiğ sütlerde benzoik asit tespit edilmiştir. Bu duruma çiğ sütün asitliğinin ve özellikle de mikrobiyotasında yer alan bakteri türlerinin özellikle de koliform ve psikrofil bakterilerin neden olduğu düşünülmektedir. Örgü peynirinde depolamanın 1. gününde $10,78 \pm 4,79 \mathrm{mg} / \mathrm{kg}$ olan benzoik asit düzeyi depolama sürecinde artma ve azalma eğilimi göstermiş ve 30 . günde $7,35 \pm 3,44 \mathrm{mg} / \mathrm{kg}$ olarak saptanmıştır. Benzoik asidin oluşum mekanizmaları arasında hippurik asitten dönüşüm olduğundan hippurik asit miktarı azalırken, benzoik asit miktarı artış göstermektedir. Örgü peynirinde diğer peynir türlerine göre hayli düşük olarak saptanan benzoik asit düzeyinin peynirin üretimde kullanılan kültür florasında Lactococcus ve Streptococcus türü bakterilerin yer almasından kaynaklandığı düşünülmektedir. Bu bakteri türleri Lactobacillus türlerine göre daha düşük düzeyde benzoik asit üretmektedir. Ayrıca peynirlerde saptanan düşük düzeyde benzoik asitin peynir üretimi sırasında süte uygulanan yüksek ısıl işlem ve proseste uygulanan haşlama işlemi nedeniyle sağlanan mikrobiyal stabilitenin de neden olduğu düşünülmektedir.

Taze peynirlerde ise benzoik asit miktarı depolamanın 1. gününde $6,72 \pm 3,78 \mathrm{mg} / \mathrm{kg}$ olarak tespit edilmiş ve peynirlerin depolama süresi boyunca hemen hemen
AKAN E, YERLIKAYA O, GÜÇER L, MERIÇ Ş, ÇAKIR TOPDEMIR P, KINIK Ö değişmeyen benzoik asit miktarı depolamanın 90. gününde $11,42 \pm 4,33 \mathrm{mg} / \mathrm{kg}$ olarak belirlenmiştir. Depolama süresince taze peynir örneklerinde tespit edilen benzoik asit miktarındaki değişimin önemli olduğu görülmüştür $(p<0,05)$. Depolama süresince örgü peynir örneklerinde tespit edilen benzoik asit miktarındaki değişimin depolamanın 1. günü harici istatiksel olarak önemli olduğu görülmüştür $(p<0,05)$. Çeşitli çalışmalarda ticari starter kültür (Lactobacillus ssp., Lactococcus ssp. ve Streptococcus ssp.'lerinin değişik oranlarda yer aldığı) kullanılarak üretilen peynirlerde benzoik asit miktarlarının 2,38-14,55 mg/kg aralığında değiştiği tespit edilmiştir (Garmiene ve ark.. 2010; Han ve ark.. 2016; Park ve ark.. 2016). Bu sonuçlar elde ettiğimiz sonuçlarla paraleldir. Buna karşın Feta peynirinde fermantasyon aşamasında $12,15 \mathrm{mg} / \mathrm{kg}$ olan benzoik asit düzeyi depolamanın 30. gününde $41,80 \mathrm{mg} / \mathrm{kg}$ düzeyine ulaşmış ve depolama sırasında da önemli düzeylerde değişmemiştir (Heshmati ve ark.. 2017). Diğer taraftan taze kaşar peyniri gibi pıhtısı haşlanan bir peynir çeşidi olan örgü peynirine benzer peynir çeşitlerinden olan Gouda. Appenzeller ve Caciocavallo peynirlerinde benzoik asit miktarı yaklaşık 2-5 mg/kg olarak belirtilmektedir (Park et al., 2016). Overström ve ark. (1972) ise Gouda peynirinde benzoik asit miktarının yüzeyde 11-18 ppm, tüm kütlede ise 7-11 ppm arasında değiştiğini bildirmiştir.

Elde ettiğimiz sonuçlar bu sınırlar içerisinde bulunmasına karşın genel olarak gerek örgü gerekse taze peynirde doğal yolla oluşan benzoik asitin çiğ süt. peynir üretim yöntemleri ve kullanılan ticari kültürlerin mikrobiyal ekolojisindeki farklar ile depolama süreci ve koşullarından önemli ölçülerde etkilendiğini göstermektedir (Han ve ark., 2016; Park ve ark., 2016; Lammorino ve ark., 2011;Souza ve ark., 2003).

Peynir örneklerinin asitlik düzeyleri ve mikrobiyolojik özellikleri Çizelge 5'de verilmiştir. İlgili çizelgeden görülebileceği üzere laktik asit bakterileri ve Enterococcus sayıları tüm peynir çeşitlerinde üretim ve depolama süresince değişken seyir izlemiş ve peynir tipine, peynir üretim yöntemine ve olgunlaşma süreçlerine bağlı olarak değişim göstermiştir. Deneme peynirlerinin $\mathrm{pH}$ değerleri depolama süresince düzenli azalma eğilimi gösterirken titrasyon asitliği değerleri (\%laktik asit) düzenli artma eğilimi göstermiştir $(p<0,05)$. Öte yandan peynir tiplerinin hepsinde üretim ve olgunlaşma periyodu boyunca oldukça yüksek sayıda maya-küf sayıları ile karşılaşımıştır. Peynirlerde karşılaşılan yüksek düzeyde maya-küflerin peynirlerin üretim ve depolanmaları sırasında oluşan kontaminasyonlardan ya da tuzdan kaynaklandığı tahmin edilmektedir. Bunun yanında peynirlerde tespit edilen benzoik asit miktarının maya/küf gelişimini önleyecek düzeyde olmadığı da görülmektedir. İlgili çizelge incelendiğinde özellikle peynirlerde Lactococcus. 
Lactobacillus ve Enterococcus sayıları depolama boyunca düzensiz artış ve azalışlar göstermiş ve yüksek mikrobiyal aktiviteye karşın oluşan benzoik asit miktarı arasında bir ilişki belirlenememiştir. Ancak fermantasyon sırasında Laktobasillerin meydana getirdikleri benzoik asit miktarının daha yüksek olduğu çeşitli araştırıcılar tarafından saptanmıştır (Amipour ve ark., 2015; Lim ve ark., 2013; Hasani ve ark., 2016; Yu ve ark., 2016).

Süt ve süt ürünlerinde benzoik asit hippürik asidin benzoik aside dönüşümü yolu ile meydana gelmekte ve bu dönüşümde laktik asit bakterilerinin (LAB) büyük önemi bulunmaktadır. Öte yandan sütte doğal olarak bulunan hippürik asitin miktarı sütün elde edildiği hayvanın türüne göre değişmektedir. Örneğin koyun sütleri $(43,3 \pm 12,3$ $\mathrm{mg} / \mathrm{kg})$ keçi sütlerine $(15,5 \pm 8,3 \mathrm{mg} / \mathrm{kg})$ kıyasla daha fazla hippürik asit içermekte dolayısı ile de koyun sütlerinden üretilen süt ürünlerinde benzoik asit düzeyleri önemli derecelerde farklılık göstermektedir. Diğer taraftan Escherichia coli ve Pseudomonas fluorescens gibi bakterilerde sütte benzoik asit üretebilme kabiliyetindedir. Özellikle endüstriyel yol olarak adlandırılan peynir üretim teknolojisinde kullanılan peynir kültürlerine bağlı olarak farklı benzoik asit düzeyleriyle karşılaşımaktadır. Termofil LAB içeren kültürleri mezofil LAB karışık kültürlerinden daha yüksek düzeyde benzoik asit yeteneğindedirler. Sonuç olarak LAB. süt ürünleri. Peynir, değişik kaynaklı içecekler, et ve sebzelerin doğal florasında bulunan ve üretimde önemli rolleri bulunan bakterilerdir. Dünyada olduğu gibi ülkemizde de çok farklı peynir tipleri farklı üretim teknikleri ile üretilmekte, dolayısı ile peynirler farklı düzeylerde benzoik asit içermektedir. Örneğin yüzeysel olgunlaşan peynirlerde peynirin dış yüzeyinde biriken benzoik asit miktarının, sütte mevcut hippürik asidin dönüşümü ile oluşan benzoik asit miktarından daha yüksek olduğu belirtilmektedir. $\mathrm{Bu}$ da benzoik asidin fenil alanin degredasyonu ve benzaldehitin otooksidasyonu gibi yollarla oluşabileceğinin göstergesi olarak kabul edilebilir. Yapılan çalışmaların birinde İran da piyasadan toplanan Ultra filtre. Feta peyniri ve laktik peynir örneklerinde ortalama benzoik

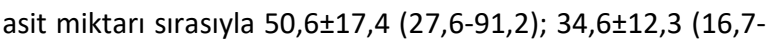
$84,1) ; 17,3 \pm 3,7(11,9-25,6) \mathrm{mg} / \mathrm{kg}$ düzeyinde bulunmuştur (Heshmati ve ark., 2017). Türkiye de ise peynirlerde benzoik asit düzeylerinin 2,3-160 $\mu \mathrm{g} / \mathrm{g}$ arasında değiştiği belirtilmektedir (Guçer ve ark., 2016; Yildiz ve ark., 2012). İtalya'da yapılan bir çalışmada değişik peynir çeşitlerinde benzoik asidin doğal olarak meydana gelebildiği ancak oluşan düzeyin $40 \mathrm{mg} / \mathrm{kg}^{\prime} ı$ altında olduğu vurgulanmıştır. Öte yandan uzun süre olgunlaştırılan ve özellikle de sert peynir tiplerinde hayli yüksek düzeyde benzoik asit oluşmaktadır. Örneğin Garmiene ve ark. (2011) sert ve yarı sert peynirlerde olgunlaşma süresince oluşan benzoik asidin 298
48 ay sonra $152 \mathrm{mg} / \mathrm{kg}$ 'a ulaştığını vurgularken; İsviçre tipi sert peynirlerde oluşan benzoik asit miktarı daha geniş sınırlarda hatta $341 \mathrm{mg} / \mathrm{kg}$ gibi uç değerlerde. Camambert ve Proses peynirlerinde ise benzoik asit miktarı 0,18-0,2 ve 0,18-20,8 $\mathrm{mg} / \mathrm{kg}$ gibi düşük düzeylerde bulunmuştur. Park ve ark. (2016) yaptıkları çalışmada ihraç ve ithal edilen peynir örneklerinden taze peynirlerde benzoik asit miktarını 2-5 mg/kg, sert peynirlerde 8,73-18,78 mg/kg düzeylerinde değiştiğini ve peynirlerin içerdiği LAB'nin cinsinin ve sayılarının oluşan benzoik asit miktarı üzerindeki etkisinin önemli olduğunu ifade etmişlerdir.

Çalışmamızda üretilen peynirlerde LAB ve Enterococcus spp. sayılarında olgunlaşma süresince düzensiz artış ve azalışlar saptanmasına karşın genelde yüksek değerler göstermiş sadece pıhtısı haşlanan geleneksel bir peynir çeşidi olan örgü peynirinde nispeten daha düşük değerler ile karşılaşılmıştır. Konu ile ilgili olarak çalışan Heshmati ve ark. (2017) LAB sayılarının Feta peynirinde fermantasyon ve olgunlaşmanın 30 günü boyunca arttığııı izleyen aşamada değişmeden kaldığını belirtmişlerdir. Buna karşın Kamleh ve ark. (2012) Hellim peynirinde başlangıçta 0,9 Log CFU/g olan LAB sayısının 3,38, 3,64 ve 3,43 Log CFU/g düzeyine $25^{\circ} \mathrm{C}^{\prime}$ de 20 gün, $15^{\circ} \mathrm{C}^{\prime}$ de 54 gün, $5^{\circ} \mathrm{C}^{\prime}$ de 170 günde ulaştığını gözlemlemişlerdir. Diğer tarafta 6 Serrena tipi peynirden 431-484 LAB izolatı elde edilmiş bu florada en yaygın türün Lactobacillus spp. olduğu saptanmıştır (Souza ve ark., 2003). Peynirlerde olgunlaşmanın ilerleyen dönemlerinde tuz ve asitlik artışına bağlı olarak Lactococcus ve Leuconostoc türleri gibi florayı oluşturan bakteriler inhibe olmaktadır. Yukarıda değinilen çalışmalarda elde edilen sonuçlar çalışmamızda elde edilen değerlerle karşılaştırıldığında sonuçların genellikle benzerlikler gösterdiği söylenebilir. Yoğurt, meyveli yoğurt, bifidobakteri türleri ile fermente edilmiş süt ürünleri, kefir, kımız gibi fermente ürünlerde ortalama değer olarak $20 \mathrm{mg} / \mathrm{kg}$ civarı benzoik asit içerebilmektedir. Sütün doğal yapısında ise iz miktarda benzoik asit bulunmakta ve yapılan çalışmalar sütün doğal yapısında bulunan hippurik asitin doğal yol ile benzoik aside dönüştürülebileceğini ortaya koymuştur. Öte yandan dönüşüm oranının sütün doğal yapısında bulunan hippurik asit miktarına bağlı olduğu ve özellikle akşam sütlerinde daha fazla hippurik asit bulunduğu dolayısı ile Stoichiometrik değişimin daha fazla olduğunu ortaya koymuştur. Ayrıca Lactococcus lactis, Escherichia coli ve Pseudomonas fluorescens'in sütte benzoik asit sentez edebileceği belirtilmektedir. Benzoik asit Quark, Cottage, sert ve yarı sert peynirlerde doğal yol ile meydana gelebilmektedir. Ancak benzoik asitin bulunma oranları ile bulunma sıklıkları arasında önemli farklılıklar bulunmaktadır. 
AKAN E, YERLIKAYA O, GÜÇER L, MERIÇ Ş, ÇAKIR TOPDEMIR P, KINIK Ö Çizelge 3. Taze ve Örgü peynirlerinin genel $\mathrm{pH}$ ve titrasyon asitliği özelliklerinde depolama süresince meydana gelen değişimler ( $n=2$ )

\begin{tabular}{|c|c|c|c|}
\hline Peynir çeşidi & Depolama günleri & pH & $\begin{array}{c}\text { Titrasyon asitliği } \\
\text { (\%Laktik asit) }\end{array}$ \\
\hline \multirow{4}{*}{ Taze Peynir } & 1 & $5,60 \pm 0,96^{a}$ & $0,31 \pm 0,16^{d}$ \\
\hline & 30 & $5,41 \pm 0,81^{b}$ & $0,44 \pm 0,11^{c}$ \\
\hline & 60 & $5,31 \pm 0,93^{c}$ & $0,52 \pm 0,19^{b}$ \\
\hline & 90 & $5,54 \pm 0,26^{a}$ & $0,75 \pm 0,16^{a}$ \\
\hline \multirow{4}{*}{ Örgü Peyniri } & 1 & $5,67 \pm 1,34^{a}$ & $0,58 \pm 0,10^{c}$ \\
\hline & 30 & $5,58 \pm 1,37^{b}$ & $0,65 \pm 0,05^{c}$ \\
\hline & 60 & $5,52 \pm 1,30^{b c}$ & $0,73 \pm 0,02^{b c}$ \\
\hline & 90 & $5,43 \pm 1,23^{c}$ & $0,81 \pm 0,08^{a}$ \\
\hline
\end{tabular}

a.b.c.d : Aynı sütunda farklı harflerle gösterilen değerler birbirinden istatiksel olarak farklıdır $(p<0,05)$

Çizelge 4. Taze ve örgü peynirlerinin üretimi ve depolanması sırasında hippurik ve benzoik asit değişimi (mg/kg)

\begin{tabular}{lcccc}
\hline & \multicolumn{2}{c}{ Taze Peynir } & \multicolumn{2}{c}{ Örgü Peyniri } \\
\hline & Hippürik asit mg/kg & Benzoik asit mg/kg & Hippürik asit mg/kg & Benzoik asit mg/kg \\
\hline Çiğ süt & $8,45 \pm 4,66^{\mathrm{a}}$ & $5,46 \pm 2,52^{\mathrm{a}}$ & $2,29 \pm 2,66^{\mathrm{a}}$ & $11,91 \pm 5,22^{\mathrm{a}}$ \\
Pastörize süt & $8,88 \pm 4,89^{\mathrm{a}}$ & $4,23 \pm 1,33^{\mathrm{a}}$ & $6,13 \pm 4,11^{\mathrm{b}}$ & $10,19 \pm 5,08^{\mathrm{a}}$ \\
1.gün & $4,28 \pm 2,33^{\mathrm{b}}$ & $6,72 \pm 3,78^{\mathrm{ab}}$ & $\mathrm{TE}(<0,5)$ & $10,78 \pm 4,79^{\mathrm{a}}$ \\
30. gün & $1,37 \pm 0,44^{\mathrm{c}}$ & $11,06 \pm 4,33^{\mathrm{c}}$ & $0,88 \pm 0,29^{\mathrm{c}}$ & $4,73 \pm 1,35^{\mathrm{b}}$ \\
60. gün & $1,04 \pm 0,25^{\mathrm{c}}$ & $10,75 \pm 5,28^{\mathrm{c}}$ & $\mathrm{TE}$ & $5,00 \pm 2,56^{\mathrm{b}}$ \\
90. gün & $\mathrm{TE}(<0,5)$ & $11,42 \pm 4,33^{\mathrm{c}}$ & $\mathrm{TE}$ & $7,35 \pm 3,44^{\mathrm{c}}$ \\
\hline
\end{tabular}

a.b.c. Aynı sütunda farklı harflerle gösterilen değerler birbirinden istatiksel olarak farklıdır $(p<0,05)$ TE: Tespit edilemedi

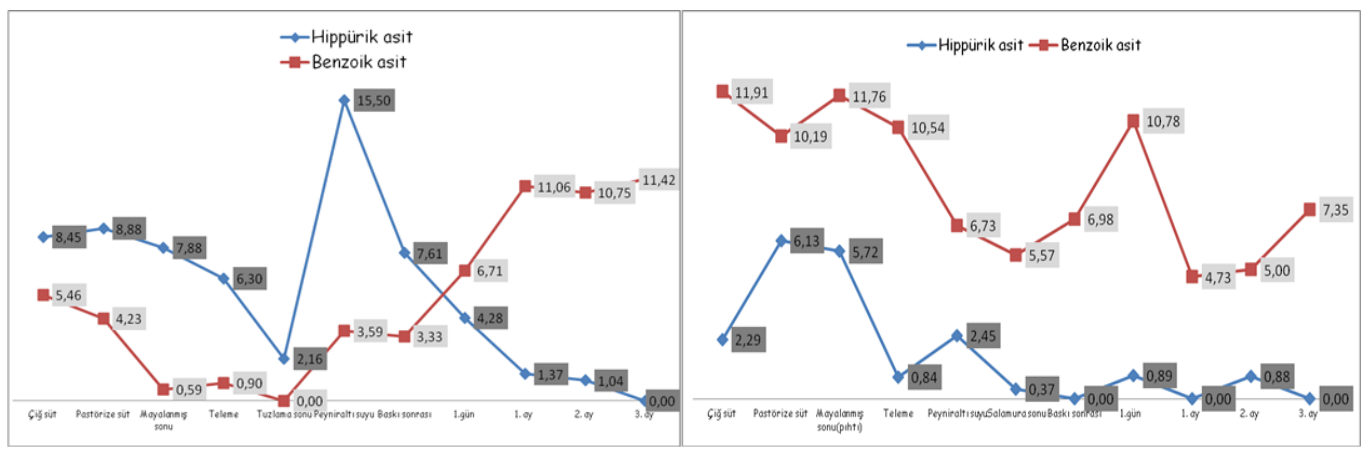

Şekil 3. Taze ve örgü peynirin 3 aylık depolama süresi boyunca hippurik asit - benzoik asit değişimi

Çizelge 5. Taze ve örgü peynirlerinin üretimi ve depolanması sırasında mikrobiyolojik özelliklerin değişimi (Log CFU/g)

\begin{tabular}{lcccc}
\hline \multirow{2}{*}{$\begin{array}{l}\text { Depolama } \\
\text { Günleri }\end{array}$} & Lactococcus spp. & Lactobacillus spp. & Enterococcus spp. & Maya-Küf \\
\cline { 2 - 5 } 1. gün & & \multicolumn{3}{c}{ Taze peynir } \\
30. gün & $6,85 \pm 0,28^{\mathrm{c}}$ & $6,54 \pm 0,03^{\mathrm{c}}$ & $5,75 \pm 0,83^{\mathrm{b}}$ & $2,03 \pm 0,04^{\mathrm{c}}$ \\
60. gün & $7,55 \pm 0,27^{\mathrm{b}}$ & $7,86 \pm 0,00^{\mathrm{a}}$ & $5,95 \pm 0,31^{\mathrm{a}}$ & $2,60 \pm 0,00^{\mathrm{b}}$ \\
90. gün & $8,24 \pm 0,16^{\mathrm{a}}$ & $7,22 \pm 0,04^{\mathrm{b}}$ & $5,50 \pm 0,17^{\mathrm{c}}$ & $3,01 \pm 0,01^{\mathrm{ab}}$ \\
\hline & $7,62 \pm 0,88^{\mathrm{b}}$ & $5,26 \pm 0,01^{\mathrm{d}}$ & $4,87 \pm 0,45^{\mathrm{d}}$ & $3,11 \pm 0,00^{\mathrm{a}}$ \\
\hline 1.gün & & Örgü Peyniri & $3,34 \pm 0,05^{\mathrm{b}}$ \\
30. gün & $7,61 \pm 1,28^{\mathrm{ab}}$ & & $3,98 \pm 0,56^{\mathrm{a}}$ & $3,28 \pm 0,16^{\mathrm{bc}}$ \\
60. gün & $7,46 \pm 0,73^{\mathrm{b}}$ & $6,17 \pm 0,45^{\mathrm{d}}$ & $3,43 \pm 0,11^{\mathrm{b}}$ & $3,42 \pm 0,50^{\mathrm{a}}$ \\
90. gün & $7,87 \pm 1,18^{\mathrm{a}}$ & $8,24 \pm 0,03^{\mathrm{a}}$ & $2,93 \pm 0,53^{\mathrm{d}}$ & $3,35 \pm 0,11^{\mathrm{ab}}$ \\
\hline a.b.c.d. Ayn & $7,51 \pm \pm 0,44^{\mathrm{c}}$ & $7,18 \pm 1,66^{\mathrm{c}}$ & $3,15 \pm 0,69^{\mathrm{c}}$ &
\end{tabular}

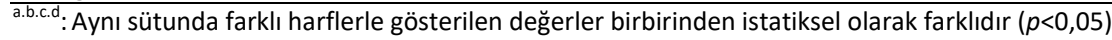




\section{SONUÇ}

Süt ürünleri arasında peynir çeşitlerinin büyük önemi bulunmaktadır. Çok sayıda çeşidi bulunan peynirlerimizin üretimi sırasında uygulanan teknoloji, peynirin geleneksel ya da endüstriyel yol ile üretim tekniği, üretimde starter kültür kullanım oranı ya da tipi (özellikle endüstriyel üretimde), mayalama sıcaklığı ve süresi, tipi, üretim mevsimi ve mevsime göre değişen mikrobiyal flora, anılan florada süt asidi bakterilerinin sayısı, ön olgunlaştırma süresi ve sıcaklığı, olgunlaşma süresi ve sıcaklığı gibi çok sayıda değişken peynir kitlesinde doğal yolla biriken benzoik asit miktarını etkilemektedir. Bu nedenle süt ve süt ürünlerinde özellikle de fermente süt ürünleri, peynir çeşitleri ile fermente süt ürünü ve peynir çeşitlerinin kullanıldığı ürünlerde en az $40 \mathrm{mg} / \mathrm{kg}$ düzeyinde benzoik asit bulunmasına izin verilmesi üreticilerin mağduriyetlerinin önlenmesinde oldukça önemli rol oynayacaktır.

\section{TEŞEKKÜR}

Projeye destek veren T.C. Tarım ve Orman Bakanlığı Tarımsal Araştırmalar ve Politikalar Genel Müdürlüğü'ne (Proje numarası: TAGEM/HSGYAD/14/A05/P01/57) teşekkür ederiz.

\section{KAYNAKLAR}

Amirpour M, Arman A, Yolmeh A, Akbari Azam M, Moradi Khatoonabadi Z (2015) Sodium benzoate and potassium sorbate preservatives in food stuffs in Iran. Food Additives and Contaminants: Part B. 8: 142-148.

AOAC (1997) Official Methods of Analysis (16th ed.) Association of Official Analytical Chemists Washington DC.

Bernardo GD, Gaudio S, Galderisi U, Cascino A, Cipollaro M (2007) Milk, dried milk, yoghurt and other fermented milks; determination of benzoic acid content. Standard 139. International dairy Federation. Brussels.

Ceylan HG, Demir T, Kurt \$̧ (2019) Geleneksel olarak üretilen Adıyaman peynirlerinin bazı fiziksel. kimyasal ve mikrobiyolojik özelliklerinin belirlenmesi. Adıyaman Üniversitesi Tarımsal Uygulama ve Arazi Yönetimi Uygulama ve Araştırma Merkezi Dergisi (ADYÜTAYAM) 7(1): 1-13.

Çelik Ş, Türkoğlu H (2007) Ripening of traditional Örgü cheese manufactured with raw or pasteurized milk: composition and biochemical properties. International Journal of Dairy Technology 60(4): 253258.

Chandan RC, Gordon JF, Morrison A (1977) Natural benzoate content of dairy products. Milchwissenschaft 32(9): 534-537.

Gardiner GE, Stanton C, Lynch PB, Collins JK, Fitzgeralt G, Ross RP (1999) Influence of a probiotic adjunct culture of Enterecoccus faecium on the quality of Cheddar cheese. Journal of Agriculture and Food Chemistry 47: 4907-4916.

Garmiene G, Salomskiene J, Jasutiené I, Macioniene I, Miliauskienè I (2010) Production of benzoic acid by lactic acid bacteria from Lactobacillus.Lactococcus and Steptococcus genera in milk. Milchwissenschaft 65: 295-298.

Garmiene G, Salomskiene J, Jasutiené I, Macioniene I, Miliauskienè I (2011) Changing benzoic acid content in cheese during its manufacture. Milchwissenschaft 66: 378-81.

Gripon JC, Desmazeaud MJ, Le Bars D, Bergere JL (1975) Etude du rôle des micro-organismes et des enzymes au cours de la maturation des fromages. Le Lait 548: 502-516.

Gucer L, Kinik O, Yerlikaya O, Meric S, Aydın E, Kılınçer M, Kurtulus G, Gur Yagli H (2016) Determination of benzoic acid content of dairy products consumed in Turkey. Journal of Food Safety and Food Quality 67(4): 93-112.

Han N, Park SY, Kim SY, Yoo MY, Paik HD, Lim SD (2016) Short communication:Change of naturally occurring benzoic acid during skim milk fermentation by commercial cheese starters. Journal of Dairy Science 99: 8633- 8637.

Hannon JK, Wilkinson MG, Delahunty CM, Wallace CM, Morrissey PA, Beresford TP (2003) Use of aoutolytic starter systems to accelerate the ripening of Cheddar Cheese. International Dairy Journal 13(11): 313-323.

Hasani S, Khodadadi I, Heshmati A (2016) Viability of Lactobacillus acidophilus in rice bran-enriched stirred yoghurt and the physicochemical and sensory characteristics of product during refrigerated storage. International Journal of Food Science and Technology 51: 2485-2492.

Heshmati A, Portaghi J, Momtaz JK, Khodadadi I (2017) Evaluation of naturally occurring benzoic acid level infeta and Cream cheese during fermentation.production.processing and storage in refrigerator. Carpathian Journal of Food Science and Technology 9(2): 143-151.

Horníčková Š, Dragounová H, Hejtmánková K, Michlová T, Hejtmánková A (2015) Production of Benzoic Acid in Fermented Goat's and Sheep's Milk. Scientia Agriculturae Bohemica 45: 247-253.

lammarino M, Di Taranto A, Palermo C, Muscarella M (2011) Survey of benzoic acid in cheeses: contribution to the estimation of an admissible maximum limit. Food Additives and Contaminants: Part B 4: 231-237.

Kamleh R, Toufeili I, Ajib R, Kanso B, Haddad J (2012) Estimation of the shelflife of Halloumi cheese using survival analysis. Czech Journal of Food Sciences 30: 512-519.

Karagözlü C, Yerlikaya O, Akpınar A, Ünal G, Ergönül B, Ender G, Uysal HR (2016) Cholesterol Levels and Some Nutritional Parameters of Traditional Cheeses in Turkey . Ege Üniversitesi Ziraat Fakültesi Dergisi, 53 (2), 161-168

Kesenkaş H, Dinkçi N, Kınık Ö (2012) Farklı işletmelerde üretilen köy peynirlerinin özellikleri. E.Ü.Ziraat Fakültesi Dergisi 49(2): 167-173. 
Leuthardt F (1977) Intermediarstoffwechsel. W. De Gruyter. Berlin. Germany. pp. 505. 657.

Lim SD, Park MS, Kim KS, Yoo MY (2013) Evaluation of benzoic acid level of fermented dairy products during fermentation. Korean Journal for Food Science of Animal Resources 33: 640-5.

Londry KL, Fedorak PM (1992) Benzoic acid intermediates in the anaerobic biodegradations of phenois. Canadian Journal of Microbiology 38: 1-11.

Olmo AD, Calzada J, Nunez M (2017) Benzoic acid and its derivares as naturally occurring compounds in foods and as additives:Uses.exposure. and controversy. Critical Reviews in Food Science and Nutrition 57(4): 3084-3103.

Overström H, Reigo J, Borgstrom S (1972) Preliminary study concerning formation of benzoic acid in cheese. Milchwissenschaft 27(11): 705-707.

Park SY, Han N, Kim SY, Yoo MY, Paik HD, Lim SD (2016) Evaluation of natural food preservatives in domestic and imported cheese. Korean Journal of Food Science and Animal Resources 36: 531-537.

Prodolliet J, Bruelhart M (1993) Determination of aspartame and its major decomposition products in food. Journal of AOAC Internatıonal 76: 268.

Renner E (1993) Practical handouts to the milk. Jestus Liebig Universitat. Giesen. Germany. 76 (Almanca).

Reuter G, Klein G (2003) Culture media for enterococci and group D-streptococci. In: Corry JEL. Curtis GDW. Baird RM (eds) Handbook of culture media for food microbiology. Elsevier. Amsterdam. pp 111-125.

Shahmohammadi M, Javadi M, Nassiri-Asl M (2016) An Overview on the Effects of Sodium Benzoate as a Preservative in Food Products. Biotechnology and Health Sciences 3(3): e35084.
AKAN E, YERLIKAYA O, GÜÇER L, MERIÇ Ş, ÇAKIR TOPDEMIR P, KINIK Ö

Sieber R, Bütikofer U, Bosset JO (1995) Benzoic acid as a natural compound in cultured dairy products and cheese International Dairy Journal 5(3): 227-246.

Souza CFVD, Dalla Rosa T, Ayub M (2003) Changes in the microbiological and physicochemical characteristics of Serrano cheese during manufacture and ripening. Brazilian Journal of Microbiology 34: 260-6.

Terzaghi BE, Sandine WE (1975) Improved medium for lactic streptococci and their bacteriophages. Applied Microbiology 29: 807-813.

Türkoğlu H, Ceylan ZG, Dayısoylu KS (2003) The microbiological and chemical quality of Orgu Cheese produced in Turkey. Pakistan Journal of Nutrition 2(2): 92-94.

Urbiene S, Leskauskaite D (2006) Formation of some organic acids during fermentation of milk. Polish Journal of Food and Nutrition Sciences 56(3): 277281.

Qi P, Hong H, Liang X, Liu D (2009) Assessment of benzoic acid levels in milk in China. Food Control 20: 414-418.

Yildiz A, Erdogan S, Saydut A, Hamamci C (2012) HighPerformance Liquid Chromatography analysis and assessment of benzoic acid in yogurt. ayran. and cheese in Turkey. Food Analytical Methods 5:591595.

Yun SS, Sang JK, Lee J, Son JS, Lee MY, Lee G, Lim HS, Kim MK (2019) Naturally occurring benzoic. sorbic and propionic acid in vegetables. Journal of Food Additives and Contaminants Part:B 12: 167-174.

Yu HS, Lee NK, Lin Jeon HL, Eom SJ, Yoo MY, Lim SD, Paik HD (2016) Benzoic Acid Production with Respect to Starter Culture and Incubation Temperature during Yogurt Fermentation using Response Surface Methodology. Korean Journal of Food Science and Animal Resources 36(3): 427 434. 
